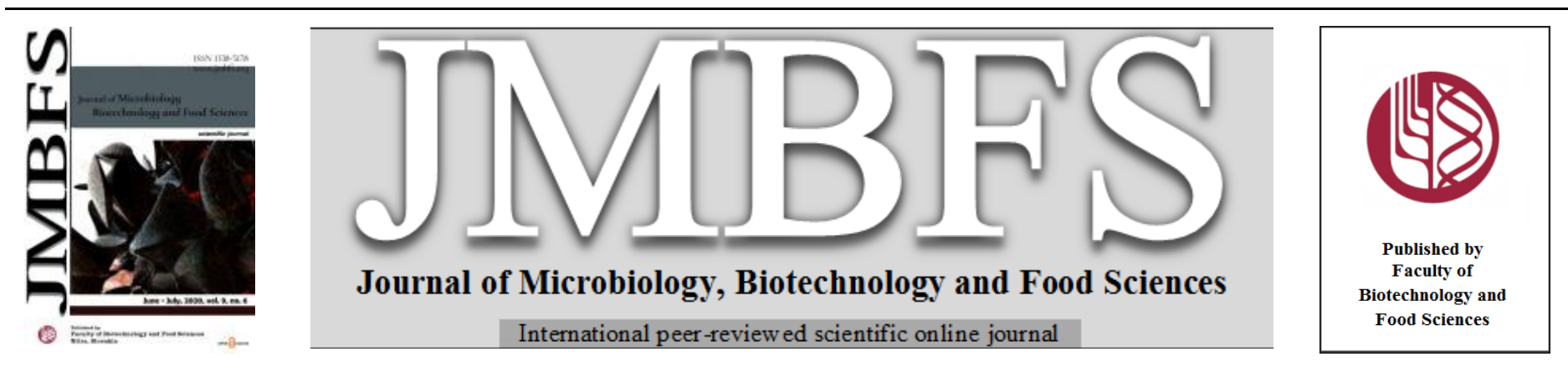

\title{
OPTIMIZATION OF OSMOTIC DEHYDRATION PARAMETERS OF BANANA UNDER PULSED MICROWAVE CONDITIONS BY RESPONSE SURFACE METHODOLOGY
}

\author{
Md. Raihanul Haque ${ }^{* 1}$, Md. Mojaffor Hosain ${ }^{2}$, Md. Murtuza Kamal ${ }^{2}$, Md. Rakibul Islam $^{l}$, Shakti Chandra Mondal ${ }^{2}$
}

Address(es):

${ }^{1}$ Department of Food Engineering and Technology, Hajee Mohammad Danesh Science and Technology University, Dinajpur-5200, Bangladesh.

${ }^{2}$ Department of Food Processing and Preservation, Hajee Mohammad Danesh Science and Technology University, Dinajpur-5200, Bangladesh.

*Corresponding author: fetraihan12@hstu.ac.bd

doi: 10.15414/jmbfs.2020.9.6.1053-1059

\section{ARTICLE INFO}

Received 17. 5. 2019

Revised 13. 12. 2019

Accepted 10. 1. 2020

Published 1. 6. 2020

Regular article

open $\odot$ access

\begin{abstract}
Microwave assisted osmotic dehydration (MWOD) conditions of banana were optimized using response surface methodology. In this study, the microwave energy was applied in pulsing form to adjust the intermittent temperature distribution and overheating problem at respective microwave power level. The experiments were conducted using a face-centered central composite design (FCCD) with four factors, viz. slice thickness $(5-10 \mathrm{~mm})$, sugar concentration $\left(40-60^{\circ} \mathrm{Brix}\right)$, microwave power $(100-1000 \mathrm{~W})$, and time (10-50 min) at three levels. Multiple regression analysis showed that all process factors significantly affects linearly on the water loss, solid gain, drying efficiency, and color difference at $\mathrm{p}<0.05$. The optimum operating conditions were found to be slice thickness of $9.87 \mathrm{~mm}$, sugar concentration of $59.99^{\circ}$ Brix, microwave power level of $100 \mathrm{~W}$, and osmosis time of $50 \mathrm{~min}$. Under this operating condition, WL, SG, color difference and drying efficiency were $19.41 \%, 6.80 \%, 15.11$ and $28.23(\mathrm{MJ} / \mathrm{kg})$, respectively. The predicted optimum values for independent variables were validated by performing several experiments and the simulated data were found in closeness to the experimental ones.
\end{abstract}

Keywords: Banana, Osmotic dehydration, Pulsed microwave, Drying efficiency, RSM

\section{INTRODUCTION}

The product obtained from osmotic dehydration belongs to the class of intermediate moisture foods (IMF). This is because intermediate moisture foods are partially dehydrated products which have the moisture content ranging from 20 to $50 \%$. Consequently, osmotically dehydrated products contain moisture in the range of $65-75 \%$ (Rao, 1997). Moreover, osmotic dehydration (OD) is a partial dehydration method which remove water from food tissues since hypertonic solution acts as a driving force for moisture diffusion (An $\boldsymbol{e t}$ al., 2013). In this process, there is no need to supply the latent heat because the moisture is removed by a physical diffusion process instead of vaporization. Therefore, the process is energy efficient (Azarpazhooh and Ramaswamy, 2012). However, OD is a slow and time-consuming process. Hence, it needs to develop novel techniques to accelerate the mass transfer rates without adversely affecting the quality of the product (Rastogi et al., 2002). Thus, a combination of osmotic dehydration with microwave drying technique may improve the drying rate by reducing the time and efficient means to reduce energy consumption (Raghavan and Silveira, 2001; Piotrowski et al., 2004).

Microwave assisted dehydration involves the transformation of electromagnetic energy into heat which is generated due to molecular excitation into the food product. Furthermore, this leads to a positive outflow of water resulting faster drying process and reduction in drying time up to $25-90 \%$ (Orsat et al., 2006; Wray and Ramaswamy, 2013; Wang et al., 2014; Abano, 2016). However, nonuniform heating of foods during microwave heating is the major drawback for its application in the food industry. This is because of nonuniform temperature distribution and central heating effects. For improving temperature uniformity, the microwave power can be applied in a pulsed form (Gunasekaran, 1999; Li et al., 2011; Sharifian et al., 2012). During pulsed drying, the total drying time was considered in two ways that were power off and power on time. The microwave power on time was referred to as the duration over which radiation energy was supplied for complete drying. In contrast, there is no radiation energy furnished during power off time since the variation of product temperature occurred at the radiation time is balanced due to the proper heat transfer. Thus, pulsed radiation controls the product temperature which enhances dried product quality and promotes energy utilization as well (Yang and Gunasekaran, 2004). Several researchers applied microwave energy during osmotic dehydration either by immersion or spray mode for various food products ( $\mathbf{L i}$ and Ramaswamy, 2006b; Azarpazhooh and Ramaswamy, 2009). Nevertheless, limited effort was drawn previously for accelerating mass transfer rate during osmotic dehydration of banana in combination with microwave energy. It is reported that the application of microwave finish drying reduced the convective drying time about $64.3 \%$ for dried banana product (Maskan, 2000)

The banana (Musa paradisica) is an important fruit crop of the world, especially in the tropical countries. Tropical countries like Bangladesh, banana is available throughout the year but significant amount of them are spoiled due to their high perishability and lack of known preservation techniques. This can lead to a huge financial loss by the grower and country as well. The most important methods that are widely practiced for preservation of fruits and vegetables are drying and dehydration (Singh et al., 2007; Taiwo and Adeyemi, 2009; Chavan et al., 2010). These methods can reduce microbial spoilage of banana during peak season and its huge wastage can be minimized. In addition to this, osmotic dehydration (OD) has received a lot of attention in recent years as an effective method to reduce the water activity of fruits and vegetables. At low water activity, the growth of microorganisms and most of the chemical reactions which deteriorate the food are ceased as well as obtain a product of more shelf stable. Therefore, the aim of this research was to optimize the process variables during osmotic dehydration of banana slices under pulsed microwave environment by response surface methodology (RSM).

\section{MATERIAL AND METHODS}

\section{Materials}

Banana (Musa paradisica) fruits of good quality and ready for ripening was purchased from the local retail (Dinajpur, Bangladesh) and allowed to ripen under natural conditions. The yellowish colored banana was selected for conducting this research. The refined sugar (Fresh refined sugar, United Sugar Mills Ltd., Narayanganj, Bangladesh) was used for preparing the osmotic solutions.

\section{Preparation of raw materials}

The osmotic solutions were prepared by dissolving required quantity of refined sugar in distilled water $(\mathrm{w} / \mathrm{v})$. The total soluble solids $\left({ }^{\circ} \mathrm{Brix}\right)$ content of the 
solution was measured using a portable digital refractometer (Model-HI96801). Consequently, the banana was washed in clean water to remove the dirt particles and peeled manually. Then the samples were sliced into different thickness using a stainless steel knife and the thickness was measured by a vernier caliper. The initial moisture content of ripe banana slices were determined using a hot air oven at $105^{\circ} \mathrm{C}$ for $24 \mathrm{~h}$ (Sutar et al., 2012; Abano, 2016). The initial moisture content of the ripe banana samples varied from $75.2 \%$ to $77.4 \%$ (wet basis).

\section{Experimental design}

The microwave assisted osmotic dehydration (MWOD) experiments were conducted using a face centered central composite design (FCCD). The four factors are sample thickness (A), sugar concentration (B), microwave power (C), and contact time (D) were taken at three level. The variable levels were chosen on the basis of previous experiments conducted by several authors (Chavan $\boldsymbol{e}$ al., 2010; Athmaselvi et al., 2012; Azarpazhooh and Ramaswamy, 2012) The experimental design included thirty experiments with sample thickness in the range of $5-10 \mathrm{~mm}$, sugar concentration in the range $40-60^{\circ} \mathrm{Brix}$, microwave power in the range $100-1000 \mathrm{~W}$, and contact time in the range $10-50 \mathrm{~min}$. The sample to solution ratio of 1:30 was kept constant throughout all the experiment (Wray and Ramaswamy, 2013). The original values of all variables in terms of coded and actual units are shown in Table 1 . All these variables were closely controlled and accurately measured during experimentation.

Table 1 Process variables and their three levels of experimental design

\begin{tabular}{cccccc}
\hline \multirow{2}{*}{ Variable } & \multirow{2}{*}{ Name } & \multirow{2}{*}{ Units } & \multicolumn{3}{c}{ Levels } \\
\cline { 4 - 6 } & & & $\mathbf{- 1}$ & $\mathbf{0}$ & $\mathbf{1}$ \\
\hline $\mathrm{A}$ & Sample thickness & $\mathrm{mm}$ & 5 & 7.5 & 10 \\
$\mathrm{~B}$ & Sugar concentration & ${ }^{\circ}$ Brix & 40 & 50 & 60 \\
$\mathrm{C}$ & Microwave power & Watt & 100 & 550 & 1000 \\
$\mathrm{D}$ & Contact time & $\mathrm{min}$ & 10 & 30 & 50 \\
\hline
\end{tabular}

\section{Experimental setup}

A domestic microwave oven (Panasonic Model NN-GD5705) with a nominal output of $1100 \mathrm{~W}$ at $2450 \mathrm{MHz}$ was used for osmotic dehydration of banana slices. Therefore, the pulsing ratio is explicated by the following equation (Hazervazifeh et al., 2018) and summarized in Table 2:

$\mathrm{PR}=\frac{\left(\mathrm{t}_{\text {on }}+\mathrm{t}_{\text {off }}\right)}{\mathrm{t}_{\text {on }}}$

Where, $t_{\text {on }}$ is the power on time $(\mathrm{min}) ; \mathrm{t}_{\text {off }}$ is the power off time (min); $\mathrm{PR}=$ Pulsing ratio

Table 2 Microwave power on and off time cycle at different pulsing ratios

\begin{tabular}{cccc}
\hline $\begin{array}{c}\text { Total drying time } \\
(\mathbf{m i n})\end{array}$ & Pulsing ratio & $\begin{array}{c}\text { On time, } \mathbf{t}_{\text {on }} \\
(\mathbf{m i n})\end{array}$ & Off time, $\mathbf{t}_{\text {off }}(\mathbf{m i n})$ \\
\hline 10 & 2 & 5 & 5 \\
30 & 3 & 10 & 20 \\
50 & 2.5 & 20 & 30 \\
\hline
\end{tabular}

\section{Experimental procedure}

Osmotic dehydration of banana slices was carried out in a batch system. The experiments were conducted at various combinations of slice thickness, sugar concentration, microwave power, and time as per the experimental design. The glass beaker containing the osmotic solution and banana slices was placed inside the microwave cavity in a sample to solution ratio of 1:30. During experimentation, agitation was not performed because it increases the cost of processing. After completion of total drying time as per experimental design, samples were withdrawn from the solution, quickly rinsed, gently blotted with paper towel to remove adhering solution, and then analyzed. Experiments were run in triplicate and the data are given an average of these results. The reproducibility of the experiments was within the range of $\pm 1.63 \%$. The water loss (WL) and solid gain (SG) were determined using a mass balance method as given by El-Aouar et al. (2006).

$$
\begin{aligned}
& \mathrm{WL}(\%)=\frac{\left(\mathrm{W}_{\mathrm{i}} \mathrm{X}_{\mathrm{i}}-\mathrm{W}_{\mathrm{f}} \mathrm{X}_{\mathrm{f}}\right)}{\mathrm{W}_{\mathrm{i}}} \times 100 \ldots \ldots \ldots \ldots \ldots \ldots \ldots \ldots \ldots \ldots \ldots \\
& \mathrm{SG}(\%)=\frac{\left(\mathrm{W}_{\mathrm{f}}\left(1-\frac{\mathrm{X}_{\mathrm{f}}}{100}\right)-\mathrm{W}_{\mathrm{i}}\left(1-\frac{\mathrm{X}_{\mathrm{i}}}{100}\right)\right)}{\mathrm{W}_{\mathrm{i}}} \times 100 .
\end{aligned}
$$

Where $\mathrm{W}_{\mathrm{i}}$ and $\mathrm{W}_{\mathrm{f}}$ are initial and final samples weights in grams at time (t), respectively; $X_{i}$ and $X_{f}$ are initial and final moisture content at time (t), respectively, $(\mathrm{g} / 100 \mathrm{~g}$ initial wet of banana slices)

\section{Drying efficiency}

Drying efficiency is defined as the energy required to evaporate a unit mass of water $(\mathrm{MJ} / \mathrm{kg})$. Drying efficiency was calculated as described by (Yongsawatdigul and Gunasekaran, 1996).

$\mathrm{DE}=\frac{\mathrm{t}_{\mathrm{on}} \times \mathrm{P} \times\left(1-\mathrm{m}_{\mathrm{f}}\right) \times 10^{-6}}{\mathrm{M}_{\mathrm{i}} \times\left(\mathrm{m}_{\mathrm{i}} \times \mathrm{m}_{\mathrm{f}}\right)}$

Where DE is the drying efficiency $(\mathrm{MJ} / \mathrm{kg}) ; \mathrm{t}_{\text {on }}$ is the total power on time (s); $\mathrm{M}_{\mathrm{i}}$ is the initial sample mass $(\mathrm{w} / \mathrm{w}) ; \mathrm{P}$ is the microwave power input (Watt); $\mathrm{m}_{\mathrm{i}}$ and $\mathrm{m}_{\mathrm{f}}$ is initial and final moisture content after $\mathrm{OD}$, respectively.

\section{Color difference}

Total color difference $(\Delta \mathrm{E})$ of fresh and osmotically dehydrated banana slices was measured with a Hunter Lab color meter (USA), Model 45/0-L. The instrument was calibrated using standard white tile before taking measurements of each sample. The color of fresh and dehydrated banana slices was assessed in terms of ' $L$ ', 'a', and 'b' after making a paste of the sample. For determining the color of the dehydrated sample, the paste was completely filled in Petri dish hence no light can pass during the measuring process. The obtained values were recorded and compared with the values of fresh banana sample. The color difference $(\Delta \mathrm{E})$ was determined by the equation given by (Giri and Prasad, 2007).

$$
\Delta \mathrm{E}=\sqrt{\left[\left(\mathrm{L}-\mathrm{L}^{*}\right)^{2}+\left(\mathrm{a}-\mathrm{a}^{*}\right)^{2}+\left(\mathrm{b}-\mathrm{b}^{*}\right)^{2}\right]}
$$

Color difference $(\Delta \mathrm{E})$ indicates the degree of overall color change of a sample while comparing color values of an ideal sample having color values of $\mathrm{L}^{*}, \mathrm{a}^{*}$, and $b^{*}$, respectively. The fresh ripe banana slices were taken as ideal sample in this case having $\mathrm{L}^{*}, \mathrm{a}^{*}$, and $\mathrm{b}^{*}$ values of $70.32,1.33$, and 31.81 , respectively.

\section{Statistical analysis}

Response surface methodology was used to determine the relative contributions of A, B, C and D to various responses under study such as water loss (WL), solid gain $(\mathrm{SG})$, drying efficiency (DE), and color difference $(\Delta \mathrm{E})$ of banana slices. The second order polynomial response surface model was fitted to each of the response variables $\left(\mathrm{Y}_{\mathrm{k}}\right)$.

$$
\mathrm{Y}_{\mathrm{k}}=\mathrm{b}_{\mathrm{k} 0}+\sum_{3}^{3} \mathrm{~b}_{\mathrm{ki}} \mathrm{X}_{\mathrm{i}}+\sum_{\mathrm{i}=1}^{3} \mathrm{~b}_{\mathrm{kii}} \mathrm{X}_{\mathrm{i}}^{2}+\sum_{\mathrm{i} \neq \mathrm{j}=1}^{3} \mathrm{~b}_{\mathrm{kij}} \mathrm{X}_{\mathrm{i}} \mathrm{X}_{\mathrm{j}}
$$

Where $b_{k 0}, b_{k i}, b_{k i i}$, and $b_{k i j}$ expressed are the constant, linear, quadratic, and cross product regression coefficients, respectively. Apart from this, $\mathrm{X}_{\mathrm{i}}^{\mathrm{S}}$ is the coded independent variable of $\mathrm{A}, \mathrm{B}, \mathrm{C}$, and $\mathrm{D}$.

The experimental design acquired from FCCD is shown in Table 3. The experimental design and data analysis was performed using a commercial statistical package, Design Expert, version 7.0 (Stat-Ease Inc., Minneapolis, $\mathrm{MN}$ ). Analysis of variance (ANOVA) was conducted to fit the model

represented by eq. (6) and to examine the statistical significance of the model terms. The adequacy of the model was assessed using model analysis, lack-of-fit tests, and $\mathrm{R}$-squared values $\left(\mathrm{R}^{2}\right.$ and Adjusted $\left.\mathrm{R}^{2}\right)$. The co-efficient of variance (CV) was calculated to find the relative dispersion of the experimental points from the predicted values of the model. Response surfaces and numerical optimization were generated using the same software.

\section{Optimization}

Numerical optimization technique was used for simultaneous optimization of the various responses. The possible goals for responses were maximized, minimized and target whether the independent variables were kept within range. In order to search a possible solution, the goals were combined into an overall composite function, $\mathrm{D}(\mathrm{x})$, called the desirability function (Montgomery, 2012) which is defined as:

$$
\mathrm{D}(\mathrm{x})=\left(\mathrm{Y}_{1} \times \mathrm{Y}_{2} \times \ldots \ldots \ldots \ldots \ldots \times \mathrm{Y}_{\mathrm{n}}\right)^{1 / \mathrm{n}}
$$

Where $Y_{i}(i=1,2, \ldots \ldots n)$ are the responses and $n$ is the total number of responses in the measure. Desirability is an objective function that ranges from zero to one and reflects the desired ranges for each transformed response. The numerical optimization sort out a point that maximizes desirability function. 
Table 3 Treatment combinations for osmotic dehydration under pulsed microwave conditions

\begin{tabular}{|c|c|c|c|c|c|c|c|c|}
\hline \multirow[b]{2}{*}{ Run } & \multirow[b]{2}{*}{$\begin{array}{c}\text { Sample } \\
\text { thickness } \\
(\mathbf{m m})\end{array}$} & \multicolumn{2}{|c|}{ Uncoded process variables } & \multicolumn{5}{|c|}{ Responses } \\
\hline & & $\begin{array}{c}\text { Sugar } \\
\text { concentration } \\
\left({ }^{\circ} \text { Brix }\right)\end{array}$ & $\begin{array}{c}\text { Microwave } \\
\text { power } \\
\text { (Watt) }\end{array}$ & $\begin{array}{c}\text { Contact } \\
\text { time } \\
(\min )\end{array}$ & $\begin{array}{c}\text { Water loss } \\
(\%)\end{array}$ & $\begin{array}{c}\text { Solid gain } \\
(\%)\end{array}$ & $\begin{array}{c}\text { Drying } \\
\text { efficiency } \\
(\mathrm{MJ} / \mathrm{kg})\end{array}$ & $\begin{array}{c}\text { Color } \\
\text { difference }(\Delta E)\end{array}$ \\
\hline 1 & 10 & 60 & 100 & 50 & 18.2 & 4.48 & 30.13 & 12.77 \\
\hline 2 & 10 & 60 & 100 & 10 & 10.7 & 3.82 & 8.70 & 9.91 \\
\hline 3 & 7.5 & 50 & 100 & 30 & 13.7 & 7.19 & 29.44 & 24.14 \\
\hline 4 & 5 & 60 & 1000 & 10 & 10.2 & 5.15 & 84.81 & 14.74 \\
\hline 5 & 5 & 40 & 1000 & 50 & 22.8 & 31.71 & 107.09 & 15.17 \\
\hline 6 & 7.5 & 60 & 550 & 30 & 18.2 & 25.87 & 59.14 & 22.8 \\
\hline 7 & 5 & 60 & 100 & 50 & 18.2 & 2.19 & 31.81 & 24.04 \\
\hline 8 & 10 & 60 & 1000 & 10 & 14.1 & 12.08 & 77.15 & 23.69 \\
\hline 9 & 5 & 50 & 550 & 30 & 17.1 & 26.80 & 57.02 & 26.29 \\
\hline $10(\mathrm{C})$ & 7.5 & 50 & 550 & 30 & 17.0 & 24.67 & 58.52 & 25.2 \\
\hline $11(\mathrm{C})$ & 7.5 & 50 & 550 & 30 & 13.3 & 19.31 & 67.44 & 25.98 \\
\hline 12 & 5 & 60 & 100 & 10 & 8.6 & 0.54 & 17.92 & 13.91 \\
\hline 13 & 10 & 50 & 550 & 30 & 17.8 & 26.37 & 51.68 & 29.9 \\
\hline $14(\mathrm{C})$ & 7.5 & 50 & 550 & 30 & 16.1 & 25.16 & 47.33 & 26.95 \\
\hline 15 & 7.5 & 50 & 550 & 50 & 21.5 & 29.36 & 83.99 & 25.84 \\
\hline 16 & 10 & 60 & 1000 & 50 & 30.7 & 65.30 & 77.74 & 38.03 \\
\hline 17 & 10 & 40 & 1000 & 50 & 17.8 & 45.62 & 97.17 & 32.32 \\
\hline 18 & 7.5 & 50 & 550 & 10 & 7.3 & 11.45 & 35.01 & 22.15 \\
\hline 19 & 5 & 40 & 1000 & 10 & 10.96 & 3.05 & 90.38 & 9.54 \\
\hline 20 & 7.5 & 50 & 1000 & 30 & 23.01 & 33.86 & 87.67 & 30.9 \\
\hline 21 & 5 & 60 & 1000 & 50 & 30.02 & 53.99 & 86.27 & 26.06 \\
\hline $22(\mathrm{C})$ & 7.5 & 50 & 550 & 30 & 14.6 & 22.17 & 60.60 & 23.85 \\
\hline 23 & 5 & 40 & 100 & 10 & 6.01 & 3.01 & 18.24 & 12.70 \\
\hline 24 & 10 & 40 & 1000 & 10 & 9.4 & 4.69 & 75.52 & 21.83 \\
\hline 25 & 10 & 40 & 100 & 10 & 5.2 & 2.35 & 15.79 & 8.01 \\
\hline $26(C)$ & 7.5 & 50 & 550 & 30 & 16.6 & 24.37 & 52.84 & 28.55 \\
\hline 27 & 10 & 40 & 100 & 50 & 10.05 & 4.49 & 33.11 & 10.85 \\
\hline 28 & 5 & 40 & 100 & 50 & 10.7 & 3.81 & 70.67 & 8.86 \\
\hline 29 & 7.5 & 40 & 550 & 30 & 9.5 & 20.90 & 74.15 & 18.01 \\
\hline $30(\mathrm{C})$ & 7.5 & 50 & 550 & 30 & 15.2 & 23.31 & 50.11 & 27.92 \\
\hline
\end{tabular}

Note: $\mathrm{C}=$ Center point

\section{RESULTS AND DISCUSSION}

\section{Model fitting}

The design and experimental data for different runs of the osmotic dehydration process are presented in Table 3. Analysis of variance (ANOVA) was conducted to determine the statistical significance of linear, quadratic, and interaction effects of various responses and the results are shown in Table 4 and 5. ANOVA indicated that the lack of fit was non-significant for all responses $(p<0.05)$ which implies that the models are sufficiently accurate for predicting the responses. The coefficient of determination $\left(\mathrm{R}^{2}\right)$ measures the goodness of fit of the model. The high values of $\mathrm{R}^{2}(>0.90)$ obtained for response variables suggested that the developed model for WL, SG, drying efficiency (DE) and color difference adequately explained the total variation in the experimental data. Furthermore, the adjusted $\mathrm{R}^{2}$ value corrects the $\mathrm{R}^{2}$ value for the sample size and for the number of terms in the model. The adjusted- $\mathrm{R}^{2}$ value was found to be $0.94,0.96,0.89$ and 0.94 for WL, SG, DE and color difference $(\Delta \mathrm{E})$, respectively. The $\mathrm{R}^{2}$ and adjusted- $\mathrm{R}^{2}$ values for the models were found quite closeness to each other, demonstrating that non-significant terms were not included. In general, the adequacy of the models was determined by the coefficient of variation (CV), which should not be greater than $10 \%$ (Giri and Prasad, 2007). Additionally, the water loss (WL) and color difference showed low CV values $(<10 \%)$, indicating that the models of these responses are highly reliable (Table 4 and 5). Therefore, the following second order polynomial equations in the form of coded factors for various responses are given below.

(8)

$$
\begin{aligned}
\mathrm{SG}= & 24.01+2.16 \mathrm{~A}+2.99 \mathrm{~B}+12.42 \mathrm{C}+10.82 \mathrm{D}+0.51 \mathrm{AB} \\
& +1.76 \mathrm{AC}+1.06 \mathrm{AD}+3.38 \mathrm{BC}+1.99 \mathrm{BD}+10.40 \mathrm{CD} \\
& +1.73 \mathrm{~A}^{2}-1.47 \mathrm{~B}^{2}-4.32 \mathrm{C}^{2}-4.45 \mathrm{D}^{2} \\
\mathrm{DE} & =57.91-5.40 \mathrm{~A}-6.03 \mathrm{~B}+29.33 \mathrm{C}+10.80 \mathrm{D} \\
\Delta \mathrm{E}= & 26.85+2.0 \mathrm{~A}+2.70 \mathrm{~B}+4.84 \mathrm{C}+3.19 \mathrm{D}-1.32 \mathrm{AB} \\
& +4.27 \mathrm{AC}+0.46 \mathrm{AD}+0.22 \mathrm{BC}+1.47 \mathrm{BD}+1.86 \mathrm{CD} \\
& +0.81 \mathrm{~A}^{2}-6.88 \mathrm{~B}^{2}+0.23 \mathrm{C}^{2}-3.29 \mathrm{D}^{2}
\end{aligned}
$$

Where, $\mathrm{WL}=$ water loss $(\%), \mathrm{SG}=$ solid gain $(\%), \mathrm{DE}=$ drying efficiency $(\mathrm{MJ} / \mathrm{kg}), \Delta \mathrm{E}=$ color difference, $\mathrm{A}=$ sample thickness $(\mathrm{mm}), \mathrm{B}=$ sugar concentration $\left({ }^{\circ} \mathrm{Brix}\right), \mathrm{C}=$ microwave power $($ Watt $), \mathrm{D}=$ contact time $(\mathrm{min})$

\footnotetext{
$\mathrm{WL}=15.90-0.036 \mathrm{~A}+3.14 \mathrm{~B}+3.76 \mathrm{C}+5.42 \mathrm{D}+0.92 \mathrm{AB}$

$-0.16 \mathrm{AC}-0.54 \mathrm{AD}+0.02 \mathrm{BC}+1.48 \mathrm{BD}+1.88 \mathrm{CD}$

$+1.13 \mathrm{~A}^{2}-2.47 \mathrm{~B}^{2}+2.03 \mathrm{C}^{2}-1.92 \mathrm{D}^{2}$
} 
Table 4 ANOVA showing the effects of the variables on WL and SG during MWOD of banana

\begin{tabular}{|c|c|c|c|c|c|c|c|c|c|}
\hline \multirow[t]{2}{*}{ Source } & \multirow[b]{2}{*}{ DF } & \multicolumn{4}{|c|}{ Water loss } & \multicolumn{4}{|c|}{ Solid gain } \\
\hline & & $\bar{\beta}$ & $\begin{array}{l}\text { Sum of } \\
\text { square }\end{array}$ & F- value & $p$-level & $\boldsymbol{\beta}$ & $\begin{array}{l}\text { Sum of } \\
\text { square }\end{array}$ & F- value & $p$-level \\
\hline Model & 14 & 15.90 & 1108.12 & 34.65 & $0.0001^{\mathrm{S}}$ & 24.01 & 7643.05 & 54.30 & $0.0001^{\mathrm{S}}$ \\
\hline Sample thickness (A) & 1 & -0.036 & 0.0227 & 0.0099 & 0.9218 & 2.16 & 84.29 & 8.39 & $0.0111^{\mathrm{s}}$ \\
\hline Sugar conc. (B) & 1 & 3.14 & 177.34 & 77.64 & $0.0001^{\mathrm{s}}$ & 2.99 & 160.69 & 15.99 & $0.0012^{\mathrm{S}}$ \\
\hline Microwave power (C) & 1 & 3.76 & 254.10 & 111.24 & $0.0001^{\mathrm{S}}$ & 12.42 & 2777.11 & 276.34 & $0.0001^{\mathrm{S}}$ \\
\hline Time (D) & 1 & 5.42 & 528.12 & 231.19 & $0.0001^{\mathrm{s}}$ & 10.82 & 2108.29 & 209.79 & $0.0001^{\mathrm{s}}$ \\
\hline $\mathrm{AB}$ & 1 & 0.92 & 13.50 & 5.91 & $0.0280^{\mathrm{S}}$ & 0.51 & 4.23 & 0.42 & 0.5261 \\
\hline $\mathrm{AC}$ & 1 & -0.16 & 0.429 & 0.19 & 0.6709 & 1.76 & 49.70 & 4.95 & 0.0591 \\
\hline $\mathrm{AD}$ & 1 & -0.54 & 4.62 & 2.023 & 0.1753 & 1.06 & 18.07 & 1.80 & 0.1999 \\
\hline $\mathrm{BC}$ & 1 & 0.020 & 0.0064 & 0.003 & 0.9585 & 3.38 & 182.83 & 18.19 & $0.0007^{\mathrm{s}}$ \\
\hline $\mathrm{BD}$ & 1 & 1.48 & 35.22 & 15.42 & $0.0013^{\mathrm{S}}$ & 1.99 & 63.36 & 6.31 & $0.024^{\mathrm{s}}$ \\
\hline $\mathrm{CD}$ & 1 & 1.88 & 56.32 & 24.66 & $0.0002^{\mathrm{S}}$ & 10.40 & 1730.59 & 172.21 & $0.0001^{\mathrm{S}}$ \\
\hline $\mathrm{A}^{2}$ & 1 & 1.13 & 3.29 & 1.44 & 0.2489 & 1.73 & 7.79 & 0.78 & 0.3924 \\
\hline $\mathrm{B}^{2}$ & 1 & -2.47 & 15.85 & 6.94 & $0.02^{\mathrm{S}}$ & -1.47 & 5.60 & 0.56 & 0.4670 \\
\hline $\mathrm{C}^{2}$ & 1 & 2.03 & 10.69 & 4.68 & 0.051 & -4.32 & 48.46 & 4.82 & $0.0442^{\mathrm{s}}$ \\
\hline $\mathrm{D}^{2}$ & 1 & -1.92 & 9.59 & 4.20 & 0.06 & -4.45 & 51.28 & 5.10 & $0.0392^{\mathrm{S}}$ \\
\hline Lack of fit & 10 & & 24.71 & 1.29 & $0.4097^{\mathrm{NS}}$ & & 127.19 & 2.70 & $0.1423^{\mathrm{NS}}$ \\
\hline $\mathrm{R}^{2}$ & & & 0.97 & & & & 0.98 & & \\
\hline Adjusted $\mathrm{R}^{2}$ & & & 0.94 & & & & 0.96 & & \\
\hline C.V. $\%$ & & & 9.98 & & & & 16.77 & & \\
\hline
\end{tabular}

Note: $\mathrm{DF}=$ degree of freedom; $\beta=$ Coefficient of estimate; $\mathrm{S}=$ significant at $5 \%$ level of significance $(\mathrm{p}<0.05)$; $\mathrm{NS}=$ non-significant at $5 \%$ level of significance $(p>0.05)$.

Table 5 ANOVA showing the effects of the variables on drying efficiency (DE) and color difference ( $\triangle \mathrm{E}$ ) during MWOD of banana

\begin{tabular}{|c|c|c|c|c|c|c|c|c|c|c|}
\hline \multirow[t]{2}{*}{ Source } & \multicolumn{5}{|c|}{ Drying efficiency } & \multicolumn{5}{|c|}{ Color difference } \\
\hline & DF & $\boldsymbol{\beta}$ & $\begin{array}{l}\text { Sum of } \\
\text { square }\end{array}$ & F-value & $p$-level & DF & $\boldsymbol{\beta}$ & $\begin{array}{l}\text { Sum of } \\
\text { square }\end{array}$ & F-value & $p$-level \\
\hline Model & 4 & 57.91 & 18768.13 & 60.13 & $0.0001^{\mathrm{S}}$ & 14 & 26.85 & 1774.67 & 32.34 & $0.0001^{\mathrm{S}}$ \\
\hline Sample thickness (A) & 1 & -5.40 & 525.05 & 6.73 & $0.0156^{\mathrm{S}}$ & 1 & 2.00 & 72.02 & 18.37 & $0.0006^{\mathrm{S}}$ \\
\hline Sugar conc. (B) & 1 & -6.03 & 653.65 & 8.38 & $0.0078^{\mathrm{S}}$ & 1 & 2.70 & 131.57 & 33.56 & $0.0001^{\mathrm{S}}$ \\
\hline Microwave power (C) & 1 & 29.33 & 15489.03 & 198.50 & $0.0001^{\mathrm{s}}$ & 1 & 4.84 & 421.42 & 107.50 & $0.0001^{\mathrm{s}}$ \\
\hline Time (D) & 1 & 10.80 & 2100.39 & 26.92 & $0.0001^{\mathrm{S}}$ & 1 & 3.19 & 183.39 & 46.78 & $0.0001^{\mathrm{S}}$ \\
\hline $\mathrm{AB}$ & & & & & & 1 & -1.32 & 27.81 & 7.09 & $0.0177^{\mathrm{s}}$ \\
\hline AC & & & & & & 1 & 4.27 & 291.77 & 74.43 & $0.0001^{\mathrm{S}}$ \\
\hline $\mathrm{AD}$ & & & & & & 1 & 0.46 & 3.33 & 0.85 & 0.3716 \\
\hline $\mathrm{BC}$ & & & & & & 1 & 0.22 & 0.74 & 0.19 & 0.6698 \\
\hline $\mathrm{BD}$ & & & & & & 1 & 1.47 & 34.62 & 8.83 & $0.0095^{\mathrm{S}}$ \\
\hline $\mathrm{CD}$ & & & & & & 1 & 1.86 & 55.48 & 14.15 & $0.0019^{\mathrm{S}}$ \\
\hline $\mathrm{A}^{2}$ & & & & & & 1 & 0.81 & 1.68 & 0.43 & 0.5224 \\
\hline $\mathrm{B}^{2}$ & & & & & & 1 & -6.88 & 122.79 & 31.32 & $0.0001^{\mathrm{S}}$ \\
\hline $\mathrm{C}^{2}$ & & & & & & 1 & 0.23 & 0.14 & 0.035 & 0.8537 \\
\hline $\mathrm{D}^{2}$ & & & & & & 1 & -3.29 & 28.12 & 7.17 & $0.0172^{\mathrm{S}}$ \\
\hline Lack of fit & 20 & & 1672.70 & 1.504 & $0.3457^{\mathrm{NS}}$ & 10 & & 43.45 & 1.41 & $0.3684^{\mathrm{NS}}$ \\
\hline $\mathrm{R}^{2}$ & & & 0.90 & & & & & 0.96 & & \\
\hline Adjusted $\mathrm{R}^{2}$ & & & 0.89 & & & & & 0.94 & & \\
\hline C.V. $\%$ & & & 15.25 & & & & & 9.27 & & \\
\hline
\end{tabular}

Note: $\mathrm{DF}=$ degree of freedom; $\beta=$ Coefficient of estimate; $\mathrm{S}=$ significant at $5 \%$ level of significance $(p<0.05)$; NS= non-significant at $5 \%$ level of significance $(p>0.05)$.

\section{Effect of process variables on water loss (WL)}

The results of WL of microwave assisted osmotic dehydration (MWOD) of banana slices are presented in Table 3. The WL during MWOD of banana slices was ranged from 5.2 to $30.7 \%$. The $p$ and $\beta$ value in Table 4 indicates that the osmosis time was the most significant variable for WL followed by microwave power and sugar concentration. These results showed that WL increased with the increase of contact time. Similar outcomes were reported during microwave osmotic dehydration of cucumber, apples and seedless guava (Fasina et al., 2002; Azarpazhooh and Ramaswamy, 2012; Ganjloo et al., 2014). However, The quadratic terms of the sugar concentration was also highly significant, whereas the quadratic terms of other process variables were non-significant $(p<0.05)$.

The combined effects of the two factors on WL can be observed graphically from the response surfaces and contour plots generated by keeping two other variables at the center levels. As microwave power and osmosis time increased, there was a continuous increase in water loss (Fig. 1A). This could be accounted for the uniform and quick heating effect of microwave energy on water molecules. Additionally, the high frequency oscillating field applied as radiation energy during OD result in the dielectric heating of water presence in cell wall of the sample. Since, the molecular movement between the sample and osmotic medium was faster with time because of the thermal energy. In consequence, it promotes moisture diffusion within the sample, thereby increasing the moisture permeability throughout the cell and mass transfer by vaporization (Azarpazhooh and Ramaswamy, 2012; Chandrasekaran et al.,2013; Venkatesh and Raghavan, 2004). Figure 1B illustrates that WL increased with the increase of sugar concentration and osmosis time. During the early stage of the process, the rate of water removal was comparatively high due to the osmotic pressure gradient between the concentrated solution and the fresh sample. After that, the rate of WL gradually settled with time towards equilibrium. Similar findings were reported by several authors for osmotic dehydration of fruits and vegetables (Li and Ramaswamy, 2006a; van Nieuwenhuijzen et al., 2001; Ramya and Jain, 2017). The thinner samples of banana slices approached equilibrium more rapidly than the thicker samples with the increase of solute concentration (Fig.1C). Nevertheless, when the osmotic solution concentration increased beyond $50^{\circ}$ Brix and slice thickness above $7.50 \mathrm{~mm}$, the rate of water removal fall apart than the beginning stage. Lerici et al. (1985) reported that the rate of water outflow depends on the dimension of sample (apple) and decreased as the sample dimension increased. 
(A)

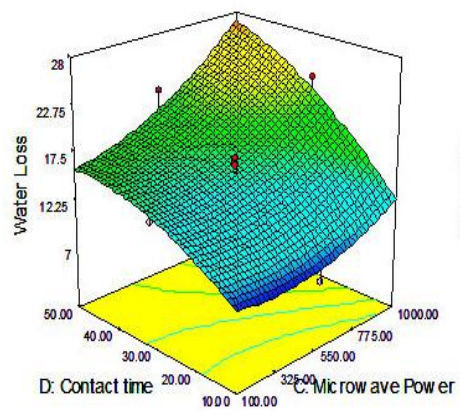

(B)

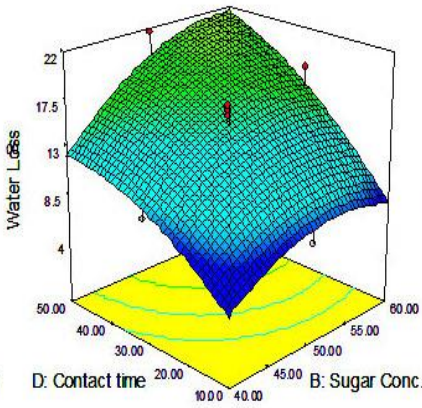

(C)

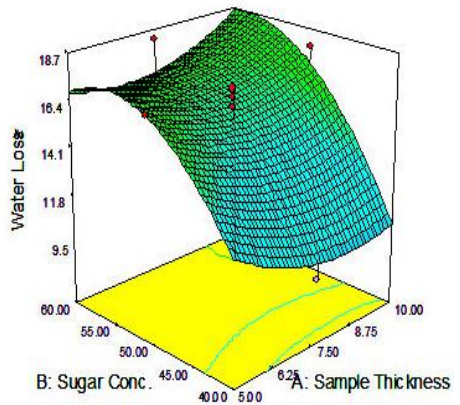

Figure 1 Effect of process variables on water loss of microwave assisted osmotic dehydration (MWOD) of banana slices under pulsed environment

\section{Effect of process variables on solid gain (SG)}

Table 3 showed that the solid gain ranges from 0.54 to $65.30 \%$, indicating that the variation between the maximum and lowest value of the solid gain was approximately $65 \%$ during microwave assisted osmotic dehydration (MWOD) at different conditions. The $p$ value in Table 4 suggests that all linear terms of process variables has significant effects on solids gain at $95 \%$ confidence level. The magnitude of $\beta$ values showed that the microwave power has the most pronounced effect on SG followed by the osmosis time, sugar concentration and slice thickness. These outcomes illustrate that the solids gain (SG) increased with an increase either of these linear variables during MWOD of banana slices. Since, the osmotic solution temperature increased with an increase of microwave power with time results in reduction of solution viscosity, permitting to penetrate more easily into plant tissues hence raising the solids gain. These results are in line with the findings of several authors (Azarpazhooh and Ramaswamy, 2012; Lazarides et al., 1995; Tiroutchelvame et al., 2019). The quadratic terms of microwave power and osmosis time has the negative and significant effect whereas the sample thickness and sugar concentration has the non-significan effect on water loss. The negative coefficient of significant quadratic terms suggested that an excessive increase in the levels of these variables resulted in the decreasing trend of SG.

It is noted from Table 4 that the interaction term 'microwave power and osmosis time' have the most significant effect on SG $(p<0.05)$. This interaction effect
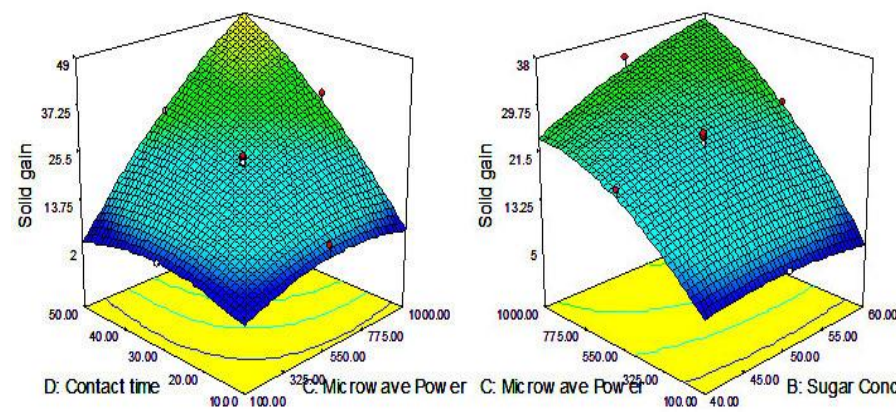

Figure 2 Effect of process variables on solid gain of microwave assisted osmotic dehydration (MWOD) of banana slices under pulsed environment

\section{Effect of process variables on drying efficiency (DE)}

Table 3 showed that the drying efficiency got during MWOD of samples was ranged from 8.7 to $107.09(\mathrm{MJ} / \mathrm{kg})$. Linear effects of all process variables on drying efficiency were highly significant $(\mathrm{p}<0.05)$. Additionally, the microwave power was the most influential variable for drying efficiency followed by the time of osmosis (Table 5). Thus, at lower microwave power levels and shorter time of osmosis can offer lower energy consumption during MWOD of banana slices under pulsed mode. This outcome was also reported by several researchers for microwave assisted osmotic dehydration of button mushrooms and cranberries (Giri and Prasad, 2007; Sunjka et al., 2008). However, sugar concentration and slice thickness has the significant negative effect on DE. This explains that an excessive increase of these variable results in the decrease in drying efficiency.

\section{Effect of process variables on color difference $(\Delta E)$}

The maximum color difference $(\Delta \mathrm{E})$ was found 38.03 , whereas the minimum was 8.01 for the dehydrated samples at different operating conditions (Table 3 ). The $p$ and $\beta$ value in Table 5 showed that the maximum positive effect of microwave

explains the increase on SG with the increase on microwave power and contact time from 30 to $50 \mathrm{~min}$ (Fig. 2A). The higher rate of SG is because of the greater exposure to microwaves, which results in a decrease in the viscosity of the osmotic solution with increased temperature over time. The higher temperatures also cause the individual cells in the sample to swell, thereby expanding the cell membrane permeability to sugar molecules thus greater solid gain (Chandra and Kumari, 2015; Wray and Ramaswamy, 2013). The interaction of sugar concentration with microwave power has the positive and significant effect on SG and contributes to enhance the magnitude of solids gain (Fig. 2B). This behavior is because of the selective absorption of microwave energy by water molecules in the fruit tissue results in an increase of internal aqueous pressure. Hence, it is advocating massive out fluxes of water from the fruit counteracting the solids uptake by the fruit (Azarpazhooh and Ramaswamy, 2009). In addition, it depicts the increase on SG with the increase on sugar concentration and osmosis period from 35 to $50 \mathrm{~min}$ in Fig.2C. Chandra and Kumari (2015) reported a similar trend that the gain in soluble solid content is a function of time. Furthermore, the solid uptake stepped up with the escalation of solute concentration (Fig.2C). This distinct behavior associated to an increase of the osmotic gradient between the fruit sample and the osmotic solution. Besides, the low molecular weight of the osmotic agent (sugar) also facilitate to penetrate easily into the cell of fruit tissue thus favored solid gain (Eren and Kaymakeasily into the cell of fruit tissue thus favored solid gain (Eren and Kaym
Ertekin, 2007; van Nieuwenhuijzen et al., 2001; Panagiotou et al.,1999).

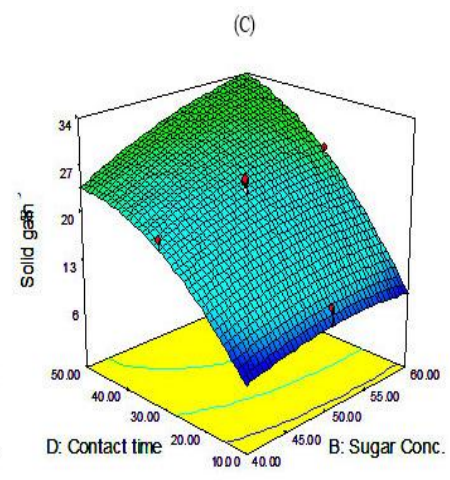

(B) power on color difference followed by contact time, sugar concentration, and sample thickness. These findings revealed that color of the osmotically dehydrated banana slices deteriorate with an increase of these linear process variables. This increase in trend enlightened the fact that the breakdown of dielectric properties of the product which leads to burning of the product surface. Since, the color properties of banana slices was affected thermally and induce to fade in color (Wang et al., 2014). Table 5 demonstrated that the quadratic terms of sugar concentration and osmosis time have the negative and significant effect on the color difference among the samples. The negative co-efficient $(\beta)$ of the quadratic variables suggested that an excessive increase of these variables resulted in the significant decrease in color properties of banana slices.

As shown in Figure $3 \mathrm{~A}$, the microwave power and slice thicknesses have the most pronounced effect on total color difference of the samples. The rate of degradation of color increases as the microwave power extends beyond 550W. This is due to absorption of more microwave energy by the dipole of the water molecule, which converted into heat hence elevating of product surface temperature and tends to scorching of the product surface (Gunasekaran, 1999). The interaction of microwave power with longer osmosis period has also the significant effect at a $5 \%$ level of significance (Fig. 3B). This phenomenon is because of the higher microwave power thus favored rapid heating of water 
molecules which create an internal pressure, promoting faster movement of water-based currents and leading to higher moisture loss from the product. Consequently, the higher water loss implies a development in the effective pigment concentration. As an effect, the selective light absorption could enhance with an increase in the refractive index in the tissue liquid phase that promotes surface reflection. These two simultaneous effects appear in divergent effects on color attributes of the product (Falade and Igbeka, 2007). Figure 3C showed that a significant increase in a color difference of banana slices with the increase of sugar concentration and contact time $(p<0.05)$. This can be explained by the

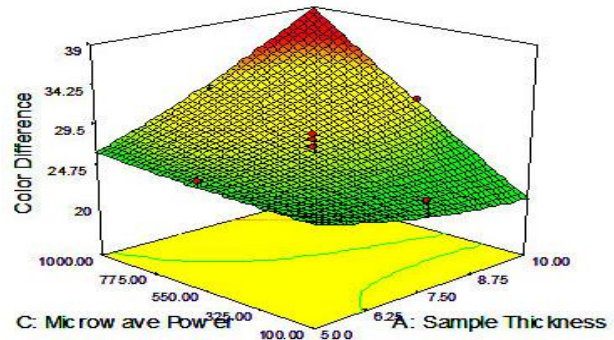

(C)

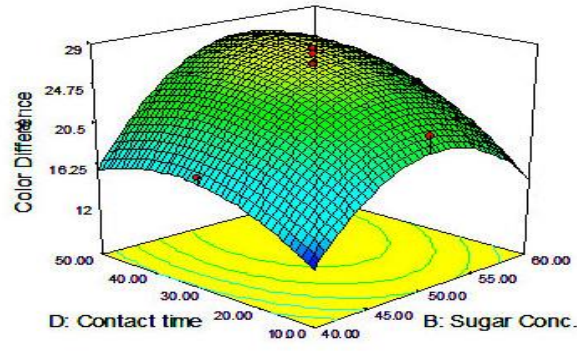

longer time exposure to air and microwaves, since the enzymatic browning escalated and cell matrix of banana shrunk which led to a change in optica performance (An et al., 2013). The change in color of banana slices is less when the thickness of sample within $7 \mathrm{~mm}$ associated with the increase of solute concentration (Fig. 3D). Krokida et al.(2001) reported that the infusion of sugars can prevent the fruit discoloration during drying for both enzymatic and nonenzymatic browning reactions.

(B)

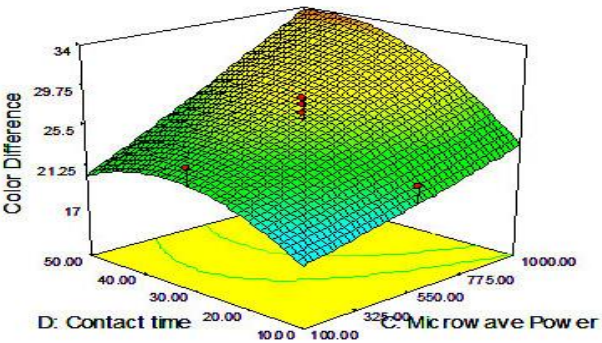

(D)

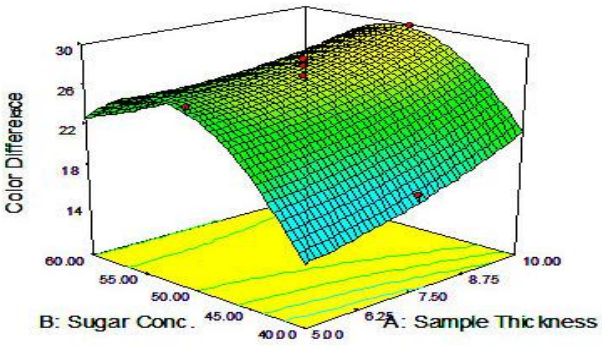

Figure 3 Effect of process variables on color difference of microwave assisted osmotic dehydration (MWOD) of banana slices under pulsed environment

Optimization of the microwave assisted osmotic dehydration (MWOD) process

Numerical optimization was performed using the developed models for water loss, solid gain, color difference and drying efficiency. The slice thickness, sugar concentration, microwave power and osmosis time were set in the range while the response WL was set at the maximum. Furthermore, the solid gain and colo difference were set at the minimum whereas the drying efficiency was set in the range. The Design Expert program was run for the optimum condition. The best solution was found with a maximum desirability value, which was selected as the optimum conditions for MWOD of banana slices. Therefore, the predicted optimum condition was obtained as slice thickness of $9.87 \mathrm{~mm}$, sugar concentration of $59.99^{\circ} \mathrm{Brix}$, microwave power level of $100 \mathrm{~W}$, and osmosis time of $50 \mathrm{~min}$. Table 6 shows the experimental value as well as predicted values of various responses at optimum condition according to the quadratic model.

Table 6 Comparison of experimental values with predicted values

\begin{tabular}{lcc}
\hline \multicolumn{2}{c}{ Responses } & \multicolumn{2}{c}{ Values } \\
\hline Water loss $(\%)$ & 19.41 & Experimental $( \pm$ SEM $)$ \\
Solute gain $(\%)$ & 6.80 & $19.52 \pm 0.20$ \\
Color change $(\Delta \mathrm{E})$ & 15.11 & $6.96 \pm 0.27$ \\
Drying efficiency $(\mathrm{MJ} / \mathrm{kg})$ & 28.23 & $16.98 \pm 1.36$ \\
\hline
\end{tabular}

\section{Validation of the model}

In terms of model validation, three experiments were performed under the recommended optimum condition with a slight alteration in slice thickness by $10 \mathrm{~mm}$ in exchange of $9.87 \mathrm{~mm}$. Moreover, Sugar concentration was replaced from $59.99^{\circ} \mathrm{Brix}$ to $60^{\circ} \mathrm{Brix}$. The experimental values (mean of three measurements) and predicted values of various responses are presented in Table 6 . The obtained experimental values were found close to the predicted values of the response surface model, which satisfy the predicted model.

\section{CONCLUSIONS}

During microwave assisted osmotic dehydration (MWOD) of banana, the osmosis time has the most significant effect on water loss (WL). It signified that when the time of osmosis increased WL also increased. However, the microwave power was found significant process variable for solid gain (SG), drying efficiency and color difference at $p<0.05$. The desirability function technique was used for finding the optimum conditions during microwave assisted osmotic dehydration (MWOD) of banana slices. By numerical optimization technique, the optimum solution was found to be $19.41 \%, 6.80 \%, 15.11$ and $28.23(\mathrm{MJ} / \mathrm{kg}$ ) for water loss, solid gain, color difference and drying efficiency, respectively. After getting optimum conditions, three experiments were carried out to validate predicted values. The experimental responses were found nearness to the predicted values from the fitted quadratic models. Therefore, microwave assisted osmotic dehydration (MWOD) in pulsed form was found as a suitable method for obtaining intermediate moisture food (IMF) products. Moreover, pulsed microwave heating can be applied during osmotic dehydration to promote mass transfer rates.

Acknowledgments: The authors are gratefully acknowledged to the University Grants Commission of Bangladesh for providing financial support during this research.

\section{REFERENCES}

ABANO, E.E. 2016. Kinetics and quality of microwave-assisted drying of mango (Mangifera indica). International Journal of Food Science, 2016 https://doi.org/10.1155/2016/2037029

AN, K.J., DING, S.H., TAO, H.Y., ZHAO, D.D., WANG, X.Q., WANG, Z.F., H U, X.S. 2013.Response surface optimisation of osmotic dehydration of chinese ginger (Zingiber officinale Roscoe) slices. International Journal of Food Science and Technology, 48(1), 28-34. https://doi.org/10.1111/j.1365-2621.2012.03153.x ATHMASELVI, K. A., ALAGUSUNDARAM, K., KAVITHA, C.V. ARUMUGANTHAN, T. 2012. Impact of pretreatment on colour and texture of watermelon rind. International Agrophysics, 26(3), 235-42. https://doi.org/10.2478/v10247-012-0035-5

AZARPAZHOOH, E., RAMASWAMY, H. S. 2009. Microwave-osmotic dehydration of apples under continuous flow medium spray conditions: comparison with other methods. Drying Technology, 28(1), 49-56. https://doi.org/10.1080/07373930903430611

AZARPAZHOOH, E., RAMASWAMY, H. S. 2012. Evaluation of factors influencing microwave osmotic dehydration of apples under continuous flow medium spray (MWODS) conditions. Food and Bioprocess Technology, 5(4), 1265-77. https://doi.org/10.1007/s11947-010-0446-X.

CHANDRA, S., KUMARI, D. 2015. Recent development in osmotic dehydration of fruit and vegetables: a review. Critical reviews in food science and nutrition, 55(4), 552-61. https://doi.org/10.1080/10408398.2012.664830 
CHANDRASEKARAN,S.,RAMANATHAN, S., BASAK, T. 2013. Microwave food processing-a review. Food Research International, 52(1), 243-61. https://doi.org/10.1016/j.foodres.2013.02.033

CHAVAN, U. D., PRABHUKHANOLKAR, A. E., PAWAR, V. D. 2010 Preparation of osmotic dehydrated ripe banana slices. Journal of Food Science and Technology, 47(4), 380-86. https://doi.org/10.1007/s13197-010-0063-8

EL-AOUAR, Â. A., AZOUBEL, P. M., BARBOSA, J.L. JR., MURR, F. E. X. 2006. Influence of the osmotic agent on the osmotic dehydration of papaya (Carica Papaya L.). Journal of Food Engineering, 75(2), 267-74. https://doi.org/10.1016/i.jfoodeng.2005.04.016

EREN, I., ERTEKIN, F. K. 2007. Optimization of osmotic dehydration of potato using response surface methodology. Journal of Food Engineering, 79(1), 34452. https://doi.org/10.1016/j.jfoodeng.2006.01.069

FALADE, K. O., IGBEKA, J.C. 2007. Osmotic dehydration of tropical fruits and vegetables. Food Reviews International, 23(4), 373-405. https://doi.org/10.1080/87559120701593814

FASINA, O., FLEMING, H., THOMSON, R. 2002. Mass transfer and solute diffusion in brined cucumbers. Journal of Food Science, 67(1), 181-87. https://doi.org/10.1111/j.1365-2621.2002.tb11380.x

GANJLOO, A., RAHMAN, R. A., BAKAR, J., OSMAN, A., BIMAKR, M. 2014. Optimization of osmotic dehydration of seedless guava (Psidium Guajava L.) in sucrose solution using response surface methodology. International Journal of Food Engineering, 10(2), 307-16. https://doi.org/10.1515/ijfe-20120117

GIRI, S.K., PRASAD, S. 2007. Optimization of microwave-vacuum drying of button mushrooms using response surface methodology. Drying Technology, 25(5),901-11. https://doi.org/10.1080/07373930701370407

GUNASEKARAN, S. 1999. Pulsed microwave-vacuum drying of food. Drying Technology, 17(3), 395-412. https://doi.org/10.1080/07373939908917542 HAZERVAZIFEH, A., NIKBAKHT, A. M., MOGHADDAM, P. A. SHARIFIAN, F. 2018. Energy economy and kinetic investigation of sugar cube dehydration using microwave supplemented with thermal imaging. Journal of Food Processing and Preservation, 42(2), 1-9. https://doi.org/10.1111/jfpp.13504 WALISZEWSKI, K.N., GARCIA, R.H., RAMIREZ, M., GARCIA, M.A. 2000. Polyphenol oxidase activity in banana chips during osmotic dehydration. Drying Technology, 18(6), 1327-37. https://doi.org/10.1080/07373930008917779

KROKIDA, M. K., ZACHARIAS, B. M., GEORGE, D. S. 2001. The effect of the method of drying on the colour of dehydrated products. International Journal of Food Science and Technology, 36(1), 53-59. https://doi.org/10.1046/j.13652621.2001.00426.x

LAZARIDES, H.N., KATSANIDIS, E., NICKOLAIDIS, A. 1995. Mass transfer kinetics during osmotic preconcentration aiming at minimal solid uptake. Journal of Food Engineering, 25(2),151-66. https://doi.org/10.1016/0260 8774(94)00006-U

LERICI, C. R., PINNAVAIA, G., ROSA, M. D., BARTOLUCCI, L. 1985 Osmotic dehydration of fruit: influence of osmotic agents on drying behavior and product quality. Journal of Food Science, 50(5), 1217-19. https://doi.org/10.1111/j.1365-2621.1985.tb10445.x

LI, H., RAMASWAMY, H.S. 2006a. Osmotic dehydration of apple cylinders: I. conventional batch processing conditions. Drying Technology, 24(5), 619-30. https://doi.org/10.1080/07373930600626545

LI, H., RAMASWAMY, H.S. 2006b. Osmotic dehydration of apple cylinders: III. Continuous medium flow microwave heating conditions. Drying Technology, 24(5),643-51. https://doi.org/10.1080/07373930600626578

LI, Z. Y., WANG, R. F., KUDRA, T. 2011. Uniformity issue in microwave $\begin{array}{llll}\text { drying. } & \text { Drying } & \text { Technology, } & \text { 652-60 }\end{array}$ http://doi.org/10.1080/07373937.2010.521963

MASKAN, M. 2000. Microwave/air and microwave finish drying of banana Journal of Food Engineering, 44(2),71-78. https://doi.org/10.1016/S02608774(99)00167-3

MONTGOMERY, D.C. 2012. Design and analysis of experiments. 8th Edition, John Wiley \& Sons, New York, USA.

van

NIEUWENHUIJZEN, N.H., ZARIEFARD, M.R.,

RAMASWAMY, H.S. 2001. Osmotic drying kinetics of cylindrical apple slices of different sizes. Drying Technology, 19(3-4), 525-45. https://doi.org/10.1081/DRT-100103932

ORSAT, V., CHANGRUE, V., RAGHAVAN, G.S.V. 2006. Microwave drying of fruits and vegetables. Stewart Postharvest Review, 2(6), 4-9. https://doi.org/10.2212/spr.2006.6.4

SUNJKA, P.S., ORSAT, V., RAGHAVAN, G.S.V. 2008. Microwave/vacuum drying of carnberries. American Journal of Food Technology, 2(3), 100108. http://doi.org/10.3923/ajft.2008.100.108

PANAGIOTOU, N. M., KARATHANOS, V. T., MAROULIS, Z. B. 1999 Effect of osmotic agent on osmotic dehydration of fruits. Drying Technology, 17(1-2), 175-89. https://doi.org/10.1080/07373939908917524

PIOTROWSKI, D., LENART, A., WARDZYNSKI, A. 2004. Influence of osmotic dehydration on microwave-convective drying of frozen strawberries Journal of Food Engineering, 65(4), 519-25. https://doi.org/10.1016/j.jfoodeng.2004.02.015
RAGHAVAN, G. S. V., SILVEIRA, A. M. 2001. Shrinkage characteristics of strawberries osmotically dehydrated in combination with microwave drying. Drying Technology, 19(2), 405-14. https://doi.org/10.1081/DRT-100102913

RAMYA, V., JAIN, N. K. 2017. A review on osmotic dehydration of fruits and vegetables: an integrated approach. Journal of Food Process Engineering, 40(3),1-22. https://doi.org/10.1111/jfpe. 12440

RAO, D. N. 1997. Intermediate moisture foods based on meats-a review. Food Reviews International, 13(4), 519-51. https://doi.org/10.1080/87559129709541139

RASTOGI, N. K., RAGHAVARAO, K.S.M.S., NIRANJAN, K., KNORR, D. 2002. Recent developments in osmotic dehydration: methods to enhance mass transfer. Trends in Food Science and Technology,13(2), 48-59. https://doi.org/10.1016/S0924-2244(02)00032-8

SHARIFIAN, F., MOTLAGH, A.M., NIKBAKHT, A.M. 2012. Pulsed microwave drying kinetics of fig fruit (Ficus Carica L.). Australian Journal of Crop Science, 6(10), 1441-47

SINGH, B., PANESAR, P. S., GUPTA, A. K., KENNEDY, J. F. 2007. Optimisation of osmotic dehydration of carrot cubes in sucrose-salt solutions using response surface methodology. European Food Research and Technology, 225(2), 157-65. https://doi.org/10.1007/s00217-006-0395-9

SUTAR, P. P., RAGHAVAN, G. V. S., GARIEPY, Y., PRASAD, S., TRIVEDI, A. 2012. Optimization of osmotic dehydration of potato cubes under pulsed microwave vacuum environment in ternary solution. Drying Technology, 30(13), 1449-1456. https://doi.org/10.1080/07373937.2012.688909

TAIWO, K. A., ADEYEMI, O. 2009. Influence of blanching on the drying and rehydration of banana slices. African Journal of Food Science, 3(10), 307-15. TIROUTCHELVAME, D., MARAN, P. J., PRAGALYAASHREE, M. M. 2019. Response surface analysis and optimization of osmotic dehydration of musa acuminata slices. Journal of Microbiology, Biotechnology and Food Sciences, 8(4), 1016-20. http://doi.org/10.15414/jmbfs.2019.8.4.1016-1020

VENKATESH, M.S., RAGHAVAN, G.S.V. 2004. An overview of micrpwave processing and dielectric properties of agri-food materials. Biosystems Engineering, 88(1), 1-18. https://doi.org/10.1016/j.biosystemseng.2004.01.007 WANG, Y., ZHANG, M., MUJUMDAR, A.S. 2014. Microwave-assisted drying of foods-equipment, process and product quality. In: Tsotsas E, Mujumdar AS (eds) Modern Drying Technology. Wiley-VCH Verlag GmbH \& Co. KGaA, Weinheim, Germany, 279-315. https://doi.org/10.1002/9783527631728.ch37

WRAY, D., RAMASWAMY, H.S. 2013. Microwave-osmotic dehydration of carnberries under continuous flow medium spray conditions. International Journal of Microwave Science and Technology, 2013, 1-11. https://doi.org/10.1155/2013/207308

YANG, H. W., GUNASEKARAN, S. 2004. Comparison of temperature distribution in model food cylinders based on maxwell's equations and lambert's law during pulsed microwave heating. Journal of Food Engineering, 64(4), 44553. https://doi.org/10.1016/j.jfoodeng.2003.08.016

YONGSAWATDIGUL, J., GUNASEKARAN, S. 1996. Microwave-vacuum drying of cranberries: Part I. Energy use and efficiency. Journal of Food Processing, 20 (2), 121-43. https://doi.org/10.1111/j.1745-4549.1996.tb00850.x 